\title{
MODERATE ISLAM IN LOCAL CULTURE ACCULTURATION: The Strategy of Walisongo's Islamization
}

\section{Moh. Nailul Muna}

Ilmu Al-Qur'an dan Tafsir, Universitas Islam Negeri Sunan Kalijaga, Yogyakarta, Indonesia

\section{email: m.nailulmuna7@gmail.com}

\section{ABSTRACT}

The issue of radicalism or extremism is often addressed to Muslims today. This article aims to solve the polemic of extremism because the reading of the phenomenon of extremism is done partially and refers only to conflict areas. Therefore, a series of puzzles need to be completed through religious practices in other regions. In Indonesia, many practices manifest moderate Islamic teachings. This article focuses on the process of Islamization carried out by Walisongo, especially Sunan Kudus, as an initial search for the embryo of Islamic moderation in Indonesia. Based on Emile Durkheim's theory of social change, this article descriptivelyanalytically shows that the moderation of Islam in the archipelago has led to the Islamization carried out by Walisongo which was carried out in a peaceful, innovative, and inclusive way, so that the teachings of Walisongo continue to this day.

\section{ABSTRAK}

Isu radikalisme atau ekstrimisme sering dialamatkan kepada umat Islam dewasa ini Artikel ini bertujuan untuk memecahkan polemik ekstrimisme, karena pembacaan atas fenomena ekstrimisme bersifat parsial dan hanya mengarah kepada kawasan-kawasan konflik. Oleh karena itu, rangkaian puzzle perlu dilengkapi melalui praktik keagamaan di kawasan lain. Di Indonesia, banyak praktik yang memanifestasikan ajaran Islam moderat. Artikel ini fokus pada proses Islamisasi yang dilakukan Walisongo, terutama Sunan Kudus, sebagai upaya penelusuran awal terkait embrio dari moderasi Islam di Indonesia. Berdasarkan teori perubahan sosial Emile Durkheim, artikel ini secara deskriptif-analitis menunjukkan bahwa moderasi Islam di Nusantara bermuara kepada islamisasi yang dilakukan oleh Walisongo yang dilakukan dengan cara damai, inovatif, dan inklusif, sehingga ajaran Walisongo tetap lestari hingga saat ini.

\section{ARTICLE HISTORY}

Received 29 July 2020

Accepted 5 December 2020

\section{KEYWORDS}

Acculturation; culture; Islam; moderation; Walisongo

\section{Introduction}

The large population of Muslims in the world is accompanied by great challenges against them.

One of them is through the issue of radicalism or extremism. This issue is often addressed to Muslims today. Several cases of terror and rebellion in the Middle East have become a basis for some groups to generalize that Islam is not only a religion of grace for the universe, but also a 
religion that teaches violence. The issue of Islamic moderation needs to be raised as a new discourse or paradigm of Islamic understanding based on the values of tolerance (tasâmuh) and brotherhood (ukhuwah), while promoting unity. ${ }^{1}$

One of the regions where the majority of the population is Muslim is Indonesia. Islam in Indonesia is interesting, because it has syncretic nuances. However, syncretic Islam, on the one hand, actually gives a different nuance to the religion. Syncretic Islam contains many moderate Islamic values that can embrace the adherents of other religions, not hostile to them. This statement refutes the opinion of Magdy B. Behman, a Professor of Intercultural Studies and World Religions at Eastern Mennonite University, Virginia, who says that basically Islamic moderation does not exist, because according to him, it is muslims who are moderate, not Islam. Therefore, different attitudes and behavior in each region inhabited by Muslims, both in the Middle East and Asia, are often found. ${ }^{2}$

This article aims to solve the polemic of extremism that tarnishes the dignity of Muslims as a whole, because the reading of the phenomenon of extremism is done partially and refers only to conflict areas. Therefore, a series of puzzles needs to be completed through religious practices carried out in other regions, such as in Indonesia.There are many practices that manifest moderate Islamic teachings in Indonesia. The object of study of this article focuses on the Islamization process carried out by a number of legendary figures who has spread Islam in the Land of Java, namely Walisongo as an initial search for the embryo of Islamic moderation in Indonesia.

Islamization in Indonesia did not happen by accident. There are several theories about the early arrival of Islam in Indonesia. Referring to Arabic theory, Islam has come to Indonesia since the seventh century AD. ${ }^{3}$ At that time, Indonesia still had a strong Hindu culture, which was the religion of the majority of the indigenous population. The teaching of Islam, which is the religion of immigrants in the Malay-Indonesian archipelago, runs dynamically, because

\footnotetext{
${ }^{1}$ Ahmad Agus Mubarok and Diaz Gandara Rustam, "Islam Nusantara: Moderasi Islam di Indonesia," Journal of Islamic Studies and Humanities, vol. 3, no. 2 (2018): 154, http://dx.doi.org/10.21580/jish.32.3160.

2 Ahmad Khoiri, "Moderasi Islam dan Akulturasi Budaya: Revitalisasi Kemajuan Peradaban Islam Nusnatara," Islamadina: Jurnal Pemikiran Islam, vol. 20, no. 1 (March, 2019): 4, http://dx.doi.org/10.30595/islamadina.v0i0.4372.

${ }^{3}$ Thera many theories of the arrival of Islam in Indonesia. Among others the theory of India and China theory. Azyumardi Azra, Islam Nusantara: Jaringan Global dan Lokal, trans. Iding Rasyidin (Bandung: Mizan Pustaka, 2002), p. 28.
} 
Indonesia as a multicultural country cannot be separated from the aesthetic dimension in daily practices, which is rich in religious culture that developed previously.

The question is: is it true that the initial model for the development of Islam in Indonesia is the same as the development of Islam in Arab lands? While, in the past, the agent of change was centered on the figure of the Prophet Muhammad, the process of Islamization in Indonesia is different from the Islamization process in Arabic because Java has its own agent of change that can refer to the wali Allâh or better known as Walisongo. This article specifically discusses the spread of Islam in Java, because in Java the teachings of Islam have been reconstructed by the Walisongo in such a way as to use non-violent acculturation methods when facing differences. This can be seen through the method of Walisongo in spreading Islam in Indonesia.

Based on the reality, the social changes of the Malay-Indonesian archipelago from time to time are evident. To describe it more systematically, the author applies Emile Durkheim's (1858-1917) theory of social change. According to Durkheim, the sequence of transformational causality originates from changes in cultural structures to social structures, and finally to engineering structures. The cultural structure that he refers to is in the form of collective sentiments or social values. These collective sentiments are essentially the basis of social cohesion and integration, so that they transcend material relations that occur in real terms in society.

Durkheim's theory shows changes in the cultural structure, that is, changes in social values will affect changes in the social structure. Because the social structure is a matrix of social institutions, including leadership institutions in society, changes in cultural structures in turn will also affect changes in technical structures. ${ }^{4}$ Although there are other Western theories related to social changes such as the theory of Karl Marx (1818-1883) and Marx Weber (18641920), Durkheim's theory is most relevant to social changes in Islam, including those happened at the beginning of the development of Islam in Java.

\section{Walisongo: Ulama and the Agent of Alteration}

For the Indonesian Muslim community, Walisongo is associated with the existence of sacred figures in Java who played an important role in the spread and development of Islam in the $15^{\text {th }}$ and $16^{\text {th }}$ centuries AD. From a language aspect, the word "walisongo" is a compound word

\footnotetext{
${ }^{4}$ Kuntowijoyo, Paradigma Islam: Interpretasi untuk Aksi (Yogyakarta: Tiara Wacana, 2017), pp. 370-1.
} 
consisting of Arabic and Javanese. The word "wali" can refer to the word walı Allâh, which means "one who loves and is loved by Allah", while the word "songo" derives from the Javanese language which means "nine". So, walisongo means "the nine saints".

The Walisongo in this article are the nine wali or ulama who played an important role in spreading Islam in Java in the $15-16^{\text {th }}$ century AD. Amongst the Javanese people, there is no a consensus about Walisongo. However, in general the walis who are considered part of Walisongo are: Maulana Malik Ibrahim (Sunan Gresik) [d. 1419], Raden Rahmat (Sunan Ampel) [1401-1481], Raden Paku (Sunan Giri) [1442-1506], Syarif Hidayatullah (Sunan Gunung Jati) [1448-1568], Makdum Ibrahim (Sunan Bonang) [1465-1525], Raden Qasim (Sunan Drajat) [1470-1522], Raden Syahid (Sunan Kalijaga) [1460-1513], Ja'far Shadiq (Sunan Kudus) [d. 1550], and Raden Prawata (Sunan Muria). ${ }^{6}$

A different view is expressed by Raden Mohammad Adnan (1889-1969) that the word "songo" does not refer to the meaning of numbers, but rather means "commendable" because the word "songo" is taken from the word "tsanâ". It is possible that Walisongo can mean "the nine saints", even though the number of wali who spread Islam in Java is not only nine people. The Javanese choose only a certain number because it is closely related to the basis of their classification. Nine is a mystical number in pre-Islamic Javanese society, which is based on the classification that humans and the universe are closely related. According to the Javanese, each of all objects in nature has its own place, the whole of which is a complete whole. In this classification, certain numbers have magical powers as a result of the influence of the order of the cosmos. The Javanese believe that the universe is governed, led, and protected by the gods who reign in all the cardinal points. There are eight cardinal guardian deities and one deity as guardian and protector of the central direction, so the total is nine. ${ }^{7}$

According to Denys Lombart, based on the place where it spread, Islamization in Java can be divided into two stages. First, Islamization in the north coast. Second, Islamization in the hinterland which gradually gave rise to a kind of Islamic bourgeoisie in the countryside. The second stage gave rise to early Islamic institutions called pesantren and tarekat groups. ${ }^{8}$

\footnotetext{
${ }^{5}$ Agus Sunyoto, Atlas Walisongo (Bandung: Mizan, 2016), p. 130.

${ }^{6}$ Ridin Sofwan, et. al., Islamisasi di Jawa: Walisongo, Penyebar Islam di Jawa Menurut Penuturan Babad (Yogyakarta: Pustaka Pelajar, 2004), pp. 13-4.

${ }^{7}$ The nine deities refered to here are north: Kuwera, northeast: Icana, east: Indra, southeast: Agni, south: Kama, southwest: surya, west: Varuna, northwest: Vayu, and the centert: Ciwa. Ibid., p. 9-10.

${ }^{8}$ Nor Huda, Islam Nusantara (Yogyakarta: Ar-Ruzz Media, 2013), p. 40.
} 
According to Lathiful Khuluq's classification, there are at least five phases of spreading Islam to Javanese society. First, the Islamization carried out by Muslim traders from India and Arabia to ordinary communities on the north coast of Java. Second, the Islamization carried out by the ulama known as Walisongo. Third, Islamization under the Mataram Islamic kingdom which was centered in the inland of Java island, especially during the Sultan Agung era. Fourth, Islamization which was marked by the reform movement carried out by Islamic organizations. ${ }^{9}$

Based on these phases of Islamization in Java, the second phase of Islamization took place very fast, namely during the Walisongo era. The acceleration of Islamization that occurred was the result of Walisongo's preaching in spreading Islam in Java. The walis exercised charismatic leadership. According to Sartono, the walis not only preach culturally, but also use their authority, either in the formal form as political rulers or kings, or outside political institutions because they have strong socio-religious power. ${ }^{10}$ In general, experts are of the opinion that Islam in Indonesia was propagated through peaceful means. There is no special mission such as in Protestant and Catholic religions to spread religion in Indonesia. ${ }^{11}$

Based on the Babad Tanah Jawi, the success of Islamization in Java started when Raden Patah (1455-1518) has studied Islam from Sunan Ampel in Surabaya. After becoming the King of Demak, Raden Patah with the support of the walis spread Islam in the archipelago. The success of the Islamization in the archipelago was not only carried out by the Walisongo movement, but also assisted by the sufis who managed to convince the kings in the archipelago. In the Malay History text, Maulana Abu Bakr, a sufism expert with his book Darul Mandzum, was able to attract the interest of the Malay community to embrace Islam. ${ }^{12}$ This also indicates the unity and cohesiveness of the ulama which was pioneered by Walisongo in efforts to Islamize the archipelago, especially in Java.

Changes made by Walisongo were not easy. From the historical aspect, Islam is a new arrival religion that disturbed the existence of longstanding religions in the Malay-Indonesian archipelago. Since the $5^{\text {th }}$ and $8^{\text {th }}$ centuries AD, Hinduism and Buddhism entered Java, which

\footnotetext{
${ }^{9}$ Ibid., p. 40.

${ }^{10}$ Sartono Kartodirdjo, Pengantar Sejarah Indonesia Baru: 1500-1900 (Jakarta: Gramedia Pustaka Utama, 1992), p. 26.

${ }^{11}$ Huda, Islam Nusantara, p. 40.

${ }^{12}$ Maharsi, Islam Melayu vs Jawa Islam: Menelusuri Jejak Karya Sastra Sejarah Nusantara (Yogyakarta: Bidang Akademik, 2008), p. 251.
} 
then profoundly influenced the civilization of this region, and even shaping it over a span of approximately a thousand years. ${ }^{13}$

Islam did not come into Java by force, as in many other Islamic regions or countries. Almost no wali were martyred in Java. ${ }^{14}$ This leads to some speculation. First, a Javanese wali has supernatural powers and this is often found in Javanese chronicles. Second, the Indonesian people have always had a friendly attitude and were able to accept new teachings. The second speculation still raises skepticism when referring to wars between kingdoms. Third, Walisongo's preaching uses local culture and the principles of good advice. The third speculation is more accurate based on Walisongo's historical remains, such as the Menara Kudus building, Javanese poetry, gamelan, and wayang. However, there are a few teachings of the walis that contain elements of violence, which resulted in the community rejection.

Although it does not deny the existence of elements of violence completely, the current acceptance is due to a cultural approach and tolerance. This indicates that the preaching of Islam that was spread by Walisongo was not preaching violently and tends to force, but it was done gradually accompanied by approaches to Indonesian culture and civilization. Evidence of the gradual change carried out by Walisongo is the shift from a culture of respecting and seeing certain objects as sacred things before the arrival of Islam to become Islamic practices, as in the case of grave pilgrimages.

One of the examples is the sacred complex of Sunan Gunung Jati which includes the Sembung hills and Gunung Jati hills. Gunung Jati Hill has been sacred since pre-Islamic times. Local people still remember that the fire was sometimes lit massively at its peak, which was considered and sacred as the midpoint of the universe. These ancient beliefs can slowly be integrated within the framework of Islam by building a burial area on the mountain. Sunan Gunung Jati is a footprint of the continuity of Islamic teachings, especially in the Gunung Jati area. $^{15}$

${ }^{13}$ Henri Chambert-Loir and Claude Guillot, Ziarah Wali dan Dunia Islam (Jakarta: Komunitas Bambu, 2010), p. 227.

${ }^{14}$ Ibid., p. 233.

${ }^{15}$ Ibid., p. 228. 


\section{The Strategy of Islamization in the Indonesian Archipelago}

The spread of Islam in the Indonesian archipelago did not happen by accident. The success of spreading Islam happened through various means and strategies. Among others are: ${ }^{16}$ first, the trade route. Since long time ago, the economic aspect of the archipelago has been the concern of various countries, which have been taken advantage of by traders from various countries, such as Arab, Persian, Indian, Malay, and Chinese to create an Islamic community, and at last to form a Muslim community. Beside trading, Muslim missionaries from the various countries also spread their religion through shipping. ${ }^{17}$ Second, the da'wah route. Da'wah bi alhâl (da'wah through action) is carried out by the traders dâa $\hat{\imath}$. The majority of Western scholars embrace the theory that the first bearers of Islam in the archipelago were Muslim merchants who brought Islam along with their merchandise. Third, through marriage. Muslim merchants married the indigenous people. The formation of Muslim families which are the nucleus of the Muslim community then plays a major role in spreading Islam. ${ }^{18}$ This way of Islamization is related to the model of spreading Islam through the economic route, because the economic centers then developed into centers of education and the spread of Islam, such as the Kingdom of Samudera Pasai which became the first center of $d a$ 'wah and education in which students visited and sent local preachers, one of which was sending Maulana Malik Ibrahim to Java. Fifth, the cultural route, namely by using local culture that is harmonized with Islamic teachings. In general, this route can be divided into two directions, namely Islam which influenced and which was influenced; Islam adapts to local culture in Java and culture adapts to Islam in Sumatera. ${ }^{19}$

However, these methods are not standard. According to A. H. Johns, it was actually a sufi wanderer who widely practiced Islamic $d a^{\prime}$ wah. They succeeded in Islamizing large populations of the Malay-Indonesian archipelago since at least the $13^{\text {th }}$ century AD. The success of

${ }^{16}$ Nusantara is a term used to describe the Indonesian archipelago that stretches across the tropics from Sumatra in the west to Papua in the east. The word Nusantara can also refer to a series of islands which are the territory of the Majapahit Kingdom. This term first appeared in the $14^{\text {th }}$ century AD. KH. Abdurrahman Wahid, et. al., Islam Nusantara (Bandung: Mizan Pustaka, 2016), p. 191.

17 Achmad Syafrizal, "Sejarah Islam Nusantara," Islamuna: Jurnal Studi Islam, vol. 2, no. 2 (December, 2015): 241, http://dx.doi.org/10.19105/islamuna.v2i2.664.

${ }^{18}$ Azra, Islam Nusantara, p. 31.

${ }^{19}$ Abdul Karim, Sejarah Pemikiran dan Peradaban Islam (Yogyakarta: Pustaka Book Publisher, 2007), p. 33. 
Islamization was mainly due to the ability of the sufis to present Islam in a form that emphasized the harmony of Islam with traditional beliefs and practices rather than change. ${ }^{20}$

The walis' strategies in spreading Islam in Java include:

First, the da'wah is done gradually. The walis are aware that since the time of Prophet Muhammad, Islam was not introduced suddenly, but required an adjustment and a long process. In fact, sometimes practices that are contrary to Islam are not prohibited immediately. As when people drank wine, the Prophet initially only explained the benefits and dangers of liquor (surah al-Baqarah [2]: 219). After a while, the ban on drinking wine was totally enforced (surah al-Mâ'idah [5]: 90). This kind of practices has also occured in the archipelago, such as animistic practices: ${ }^{21}$ This kind of practices has also occured in the archipelago, such as animistic practices: they worshiped trees and statues, and provided offerings, but Walisongo leaves them at a certain tempo. Gradually, the practices were straightened or changed with the acculturation of Islamic culture. This does not mean mixing the teachings of Islam because the fundamental values of Islam in the acculturation of local culture are maintained.

Second, it was done by not hurting anyone ('adam al-haraj). The walis brought Islam not by destroying their traditions, not even disturbing their religion and beliefs, but by elaborating Islamic furûi $i y a h$ values in order to give birth to new traditions. This reinforces the adage that Islam is a religion of grace for the universe. Kindness and goodness are at the core of Islamic teachings which apply everywhere and at all times. ${ }^{22}$

As a comparison, in the days before the Walisongo, the da'wah was done in the form of direct oral da'wah by inviting people directly to embrace Islam. This kind of da'wah did not get a good response from the community. Moreover, the fact that the people at that time were adhered to the traditions of their ancestors, make it difficult to eliminate the practices immediately. ${ }^{23}$ The walis are fully aware that this multiethnic, muticultural and multilingual archipelago is a great gift from God. Furthermore, the natural conditions are friendly, the climate is not tropical, not too hot, nor too cold. There is no reason not to be grateful by attacking ancestral traditions in the name of religious purification which can cause harm in all

\footnotetext{
${ }^{20}$ Azra, Islam Nusantara, p. 33.

${ }^{21}$ Animism is the belief in spirits who inhabit all objects (trees, rocks, rivers, etc.). Pusat Bahasa Departemen Pendidikan Nasional, Kamus Bahasa Indonesia (Jakarta: Pusat Bahasa Departemen Pendidikan Nasional, 2008), p. 72.

${ }^{22}$ Sunyoto, Atlas, pp. xi-ii.

${ }^{23}$ Yulilatun Tajuddin, "Walisongo dalam Strategi Komunikasi Dakwah," ADDIN: Media Dialektika Ilmu Islam, vol. 8, no. 2 (August, 2014): 368-369, http://dx.doi.org/10.21043/addin.v8i2.602.
} 
areas. Islamization in the archipelago occurred through diffusive and adaptive ways, and avoided the strategy of conquest through violence, so that Islamic teachings could blend with Buddhist and Hindu traditions without destroying Islam itself. Eventually, Islam can "blend", and this happened gradually, with local culture in the archipelago. ${ }^{24}$

\section{Kejawen Culture and Islam}

It is necessary to reveal several aspects related to cultural and theological dimensions to see the distinction between Islam and Javanese culture. One of the things that stands out in the Javanese tradition is the art pattern that lives and develops along with the development of the community's character. The arts that are included in the social structure and Javanese cultural arts can be divided as follows:

First, the "alus art", which includes: (a) wayang, that is an art performance using wooden or leather puppets to dramatize Javanese and Indian versions of the stories, Mahabharata and Ramayana, or mythological versions of the history of Javanese kingdoms before the colonial period; (b) gamelan, that is a musical instrument which was usually used at that time as an accompaniment to wayang art or other art forms; (c) joged, namely the Javanese palace dance; (d) lakon, which literally means "plot" or "scenario", namely a myth that can be dramatized in wayang, but is often only told orally as is usually a myth; and (e) batik, which is a textile decoration by means of waxing and dyeing.

Second, the "rough arts" which includes: (a) ludruk, namely folk jokes involving men wearing women's clothes and lowly comedians as the main characters; (b) kledek, namely street female dancers, who dance either as "door to door" itinerant dancers or as dancers hired to celebrate marriages, circumcisions and so on; and (c) jaranan or folk dance, in which the dancers "ride" paper horses and fall into a trance, acting as if they were horses. ${ }^{25}$

Islam has regulated various human behaviors, both vertically to God ('ubûdîyah) and horizontally to humans (mu'âmalah). Islamic teachings can be divided into two forms: first, the teachings of qath $\hat{\imath}$ (basic teachings). It is fixed, absolute, dogmatic, and immutable. It consists of two parts, namely: (a) qathî al-wurûd, namely teachings whose sources of reference can be found in the Qur'an and hadith; (b) qath'î al-dalâlah, namely teachings whose meaning is absolute, because the text (nash) has only one meaning, both in the Qur'an and the hadith; and

\footnotetext{
${ }^{24}$ Edy Susanto and Karimullah, "Islam Nusantara: Islam Khas dan Akomodasi terhadap Budaya Lokal," Al-Ulum, vol. 16, no. 1 (June, 2016): 62, https://doi.org/10.30603/au.v16i1.27.

${ }^{25}$ Clifford Geertz, Agama Jawa (Jakarta: Komunitas Bambu, 2013), pp. 375-6. 
(c) qath'î al-tanfîdz, namely teachings that are compulsory, which if not done, mahk $\hat{u} m$ 'alaih (people who are subject to the law) will be deemed to violate religious provisions such as fasting and prayer. $^{26}$

Second, the 'relative' teaching, which includes all provisions that are not fixed, relative, and can change. This form is often referred to as dzannî. Like qath $\hat{\imath}, d z a n n \hat{\imath}$ also has three parts, namely: (a) dzannî al-wurûd, namely all teachings that are not taken directly from the Qur'an or hadith. This can also refer to ijtihâd (juridical reasoning) or the opinion of the imams or the Prophet's companions; (b) dzannî al-dalâlah, namely teachings whose meanings are indefinite because the text has various meanings, taken from either the Qur'an or the hadith; and (c) dzannî al-tanfîdz, namely teachings that are uncertain to enforce, such as the law on inheritance. $^{27}$

Of these two forms, Walisongo have acculturated the teachings that are $d z a n n \hat{\imath}$ in nature. Later, this is what has been accepted in various traditions and cultures in the archipelago. Therefore, there is no change inthe procedures of prayers, hajj, and other qath $\hat{\imath}$ teachings. The implication of the communication between sharia values and culture in the archipelago results in various discourses. Two of the most famous are "Islam Nusantara" and "Islam Pribumi". ${ }^{28}$ Of the two discourses, other discourses then developes such as Nusantara fiqh, Nusantara siyâsah, Nusantara qânûn, Nusantara muamalat, Nusantara Islamic banking, and Nusantara Islamic economy. ${ }^{29}$

Basically, Islam accepts the existence of other traditions and culture. However, Islam does not accept elements of animism and dynamism that violate the monotheistic concept of divinity which is the core of Islamic teachings. In order that the art, which is the tradition of Javanese people, does not contradict Islam, Walisongo acculturates and touches the theological aspects of society, so that acculturation is the most appropriate word to describe the process of cultural formation in Indonesia. Linguistically, acculturation has several meanings, namely: (a)

${ }^{26}$ Ibrahim, "Ajaran Islam dalam Pandangan Harun Nasution,” Aqidah-Ta: Jurnal Ilmu Aqidah, vol. 5, no. 2, (2019): 135, https://doi.org/10.24252/aqidahta.v5i2.12286.

${ }^{27}$ Ibid., p. 136.

${ }^{28}$ Lutfi Rahmatullah, "Eksistensi Hukum Islam di Tengah Keragaman Budaya Indonesia: Perspektif Baru Sejarah Hukum Islam dalam Bingkai Dialektika Nilai-nilai Syari'ah dan Budaya," Al-Manâhij: Jurnal Kajian Hukum Islam, vol. 10, no. 1 (2016): 74, https://doi.org/10.24090/mnh.v10i1.917.

${ }^{29}$ Khabibi Muhammad Luthfi, "Islam Nusantara: Relasi Islam dan Budaya Lokal," Shahih: Journal of Islamicate Multidisciplinary, vol. 1, no. 1 (June, 2016): 4, http://dx.doi.org/10.22515/shahih.v1i1.53. 
mixing of two or more cultures; and (b) the process of a foreign culture influence in a society with different levels of absorption. ${ }^{30}$

The problem of Kejawen culture lies in the practice associated with asceticism and the early wayang traditions which all lead to one point, namely polytheism or denial of the oneness of God. Although the Javanese view of the polytheism varies, what is held here is the Islamic

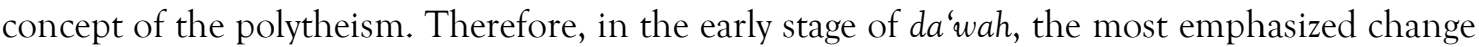
is the theological aspect, namely the way of implementing Islam into the soul of society because it is the elements of belief that affect the cultural and social structures. Acculturation is a successful method to instill and ground this theological teaching.

The walis realize that the way to reconcile existing differences is to find common ground or similarities. The sufistic element becomes a link between Islamic teachings and the HinduJavanese tradition. The teachings of sufism which were later elaborated with Hindu-Islamic culture made Islam give a new color to the existing culture, without completely eliminating the previous heritage. In the Islamic history, sufis have expressed the greatest willingness and openness to terms from non-Muslim beliefs and rites. In general, the sufis in South Asia are willing to accept elements of the Hindu and Buddhist traditions, which in their terms, are $d z a ̂ h i r$ (external), but reject those that can only be interpreted as inner (internal). The form of elaboration becomes clearer when it refers to developing practices, such as prayer beads and breath mastery exercises. However, they reject the reincarnation (rebirth) model and the caste system. $^{31}$

\section{Walisongo's "Islamic Product"}

Islam brought by Walisongo was successfully wrapped in a new container that attracted the public. One of the walis who significantly offered a "new product of Islam" was Sunan Kudus. The wali who lived in Kudus brought new teachings of Islam which emphasizes aspects of tauhîd (monotheism). The offer sounded strange at the time and went against the teachings of the local people, so he faced a big challenge. The important value that can be taken from this confrontation is that Sunan Kudus did not preach frontally by conveying Islamic teachings as a whole (kâffah) and at once (faurî). However, he chose to acculturate local culture, which is close to Hindu tradition, with Islamic teachings as a strategy for Islamic da'wah.

\footnotetext{
${ }^{30}$ Pusat Bahasa Departemen Pendidikan Nasional, Kamus Bahasa Indonesia (Jakarta: Pusat Bahasa, 2008), p. 33.

${ }^{31}$ Mark R. Woodward, Islam Jawa, trans. Hairus Salim (Yogyakarta: LKiS. 2006), pp. 325-6. 
Sunan Kudus tried to bring new cultural elements that were full of Islamic values, but still maintained the old cultural elements inherent in the Kudus community at that time. The old culture is full of beliefs that tend to conflict with tanhîd, such as the social structure was built with a caste system or differences in class groups, so that it could lead to social life that tend to be discriminatory. Sacred were manifested in the form of statues and certain animals that were considered to have sacred values, and then what prominent is the belief in many Gods or polytheism.

The acculturation pattern carried out by Sunan Kudus can be mapped as follows: ${ }^{32}$

First, architecture. The pattern of acculturation of Hindu-Buddhist local culture with Islam in the most obvious form of architecture is found in the Menara Kudus building, which becomes the pride of Muslims until now. The Hindu cultural heritage is still evident in the building, which is not much different from the temple buildings in Bali. However, its function has changed, in which previously it served as a place of worship, but now it becomes a place to call to prayer. According to Nur Said, the acculturation pattern can also be seen in the eight showers (ancient padasan). Each shower is decorated with a relief of statue as an aesthetic ornament. Some say that the eight fountains of wudu were adopted from the Buddhist teachings of asțangika-mārra, namely the eight main paths related to important values in life such as knowledge, decisions, actions, way of life, effort, mediation, and wholeness.

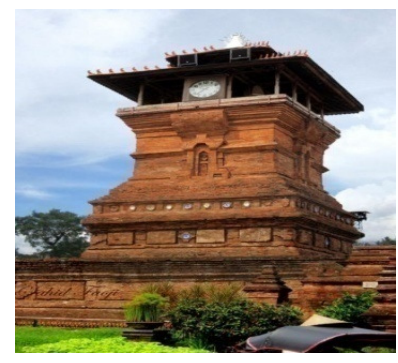

Sunan Kudus truly understood the power of two sciences as weapons in the indigenousization of Islam, namely sufism (tashawwuf) and the ushûl al-figh. The sufism teaches empathy with local spiritual traditions, whereas the ushûl al-figh provides a contextual reading of Islamic law. This is evidenced by the existence of the symbol of "eight Buddhist paths" (asțangika-mārga) which is beautifully engraved on the wudlû' tower of the Menara Kudus. Such

${ }^{32}$ Nur Said, Jejak Perjuangan Sunan Kudus dalam Membangun Karakter Bangsa (Bandung: Brillian Media Utama, 2010), p. 72. 
symbols are not purely occult, because in Islam something esoteric has its own place, namely in the teachings of sufism. ${ }^{33}$

Second, tying cows in the courtyard of the mosque to attract people's attention to go to the mosque. At the beginning of the Islamization period the people were less enthusiastic about implementing Islamic teachings. This practice could attract the attention of the community because they thought that cows were respected animals. On the other hand, cows were a description of the classification of the caste of the society, because cows were only owned by certain people, namely the community leaders at that time.

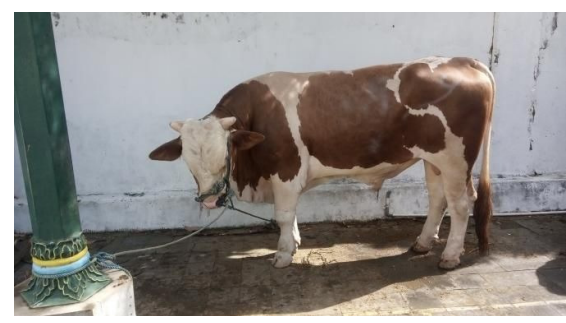

The impressive preaching of Sunan Kudus is the prohibition of slaughtering cows to attract sympathy from the public, even though this is permitted in Islam. This model of $d a^{\text {'wah }}$ succeeded in Islamizing the population of Kudus who were previously Hindus. The people of Kudus still maintain this custom until now, they do not slaughter cows even though it is Eid al-

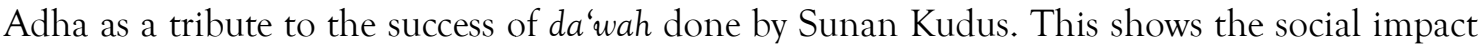
of Sunan Kudus's legacy of tolerance which is still grounded in the Kudus community to this day. Sunan Kudus prioritizes tolerance and harmony rather than conflict in spreading Islam. ${ }^{34}$ Based on Durkeim's theory, the teachings of Sunan Kudus form a social construction that understands the urgency of tolerance, which comes from practices that indirectly affect the collective sentiment of the society.

Third, composing songs and stories of monotheism. This kind of da'wah is often done by several walis. The works made by several walis show their extraordinary artistic abilities such as Sunan Kudus, known as a poet and folklore with a vision of monotheism. All is done within the framework of Islamic da'wah. Among the works of Sunan Kudus are the songs Gending Maskumambang and Mijil. Some forms of acculturation offered by Sunan Kudus when disseminating Islamic teachings in Kudus and its surroundings show that Sunan Kudus is both

33 Syaiful Arif, "Strategi Dakwah Sunan Kudus," ADDIN: Media Dialektika Ilmu Islam, vol. 8, no. 2, (August, 2014): 247-8, http://dx.doi.org/10.21043/addin.v8i2.597.

${ }^{34}$ Ibid., p. 72. 
a preacher and an agent of alteration. ${ }^{35}$ In turn, the $d a^{6}$ wah model carried out by Sunan Kudus succeeded in sowing the seeds of peace in the Kudus and surrounding areas, because the differences in belief found in Kudus did not cause conflicts, rather what appeared was tolerance and mutual respect between one group and another. The attitude of tolerance and mutual respect is unconsciously embedded in the behavior and attitude of the Kudus community, which continues even though Sunan Kudus has passed away.

In addition, there is also a wayang kulit culture which is well known in the Java. Wayang kulit is one of the many Javanese traditions that still exist today. According to Theodoor Gautier Thomas Pigeaud (1899-1988), in Javaansche Volksvertoningen, the wayang kulit purwa which is known as it is today is a product of the wali who has spread Islam. According to Soekmono (1922-1997), the basis and essence of Indonesian culture during the Middle Ages was ancient culture (original Indonesia), but it had been Islamized. The reform carried out by Sunan Kalijaga in the practice of wayang is a simple form of human-like pictures on paper, gamelan instruments as accompaniment, as well as songs and its sulukk, all of which have philosophical values of Islamic teachings. ${ }^{36}$

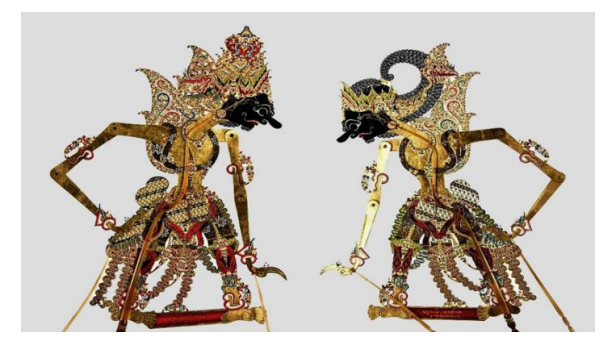

In addition, the acculturation values are also evident in religious practices such as religious ceremonies performed by the Javanese in many forms. Among others: (a) slametan, which is eating together with tumpeng rice, side dishes, chicken, water from jug, flower water, carried out after they present, the elders/ulama lead a prayer which is then followed by recitation of la ilâha illâ Allâh; (b) tingkepan, namely the seven month "mitoni" ceremony when the baby is in the womb of the mother. This ceremony does not stand alone, but it is a series of other related ceremonies, because after the baby is born and the umbilical cord is cut using a welat, the puput

\footnotetext{
${ }^{35}$ Ibid., p. 76.

${ }^{36}$ Sunyoto, Atlas, p. 417.
} 
puser ceremony is held after the umbilical cord is cut; (c) naming ceremony; (d) kekahan (cutting hair); (e) tedak siten (ground touching ceremony); and (f) khitanan (circumcision). ${ }^{37}$

\section{Moderate Islamic Values in the Indonesian Archipelago}

Based on the explanation above, the value of Islamic moderation can be found in: first, the reception of furu' teachings in the local tradition shows Walisongo's tolerance in addressing Javanese culture which does not go theologically against the main teachings of Islam. The adaptation done are only to the furû îyah (the branches of the teachings), not ushûliyah (the fundemental principles the teachings. A reception that does not deify Islamic values raises public sympathy for accepting Islam. Second, complementing each other on things related to fundamental values of Islamic teachings when the developed traditions are not in accordance with Islam, Islam does not eleminate them, but colors them to become Islamic traditions. Third, dialogue with reality. Islam welcomes diversity, which includes acculturation, assimilation, and innovation. All of this does not show that the acculturation of Islam is out of control, but the changes that occur are dynamic in minimizing the opposition and rejection of local tradition worshipers.

Walisongo with all their efforts of Islamization has proven their moderate attitude towards local culture. The moderate attitude is manifested through the adaptation of local culture and traditions with Islamic values. The proof is Raden Patah, the king of Demak, and Walisongo who took the initiative to issue policies on the protection of local cultures which manifested in various ways as long as they were not contradict the main teachings of Islam, so that the Muslim community at that time lived in harmony and side by side with all local communities although their traditional backgrounds, culture, or even religion is different. ${ }^{38}$

Based on Durkheim's theory, moderate acculturation carried out by Walisongo would indirectly construct a moderate and tolerant culture of society. Their Islamization process further strengthens Abdurrahman Wahid's idea of the indigenousization of Islam as follows: ${ }^{39}$

"The idea is intended to dissolve the pattern and character of Islam as something normative and religious practices into something contextual. In the "indigenousization of Islam", it is illustrated how Islam as a normative teaching originating from God is

\footnotetext{
${ }^{37}$ Yahya Harun, Islam Nusantara: Abad XVI EO XVII (Yogyakarta: Kurnia Kalam Sejahtera, 1995), p. 98.

38 Suparjo, "Islam dan Budaya: Strategi Kultural Songo dalam Membangun Masyarakat Muslim Indonesia,” Komunika: Jurnal Dakwah dan Komunikasi, vol. 2, no. 2 (December, 2008): 179 https://doi.org/10.24090/komunika.v2i2.100.

${ }^{39}$ Wahid, Islam Nusantara, p. 7 
accommodated into a culture that originates from humans without losing their respective identities."

The character of Islamization carried out by Walisongo shows a pattern of indigenousism that gives rise to the characteristics of the indigenous population as follows: first, contextual, namely Islam is understood as a teaching related to the context of place and time. Second, tolerance, namely the contextualization of Islam, in turn, makes us realize that various interpretations and understandings of Islam are not something deviant when ijtihâd is carried out responsibly. This attitude would lead to a tolerant attitude towards various different interpretations of Islam. The awareness of the reality of the plural Indonesian context demands a sincere recognition of the equality of religions with all its consequences. This spirit of diversity is the pillar of the birth of Indonesia. Third, respect for tradition. Islam (even at the time of the Prophet) that was built on good old traditions is a proof that Islam is not always hostile to local traditions. The tradition is not offended, but instead becomes a means of vitalizing Islamic values, because Islamic values need a framework that is familiar with the lives of its adherents. Fourth, progressive, namely Islam can adapt to the reality. The progress of the times is not understood as a threat to the basic teachings of Islam, but as a trigger to respond creatively and intensely. Fifth, liberating. Islam can answer real human problems universally regardless of religious and ethnic differences. Islam is for humans and their benefits. With the spirit of liberation, in essence, Islam will not lose its function as a religion of grace for the universe. $^{40}$

With the cultural acculturation, Islam does not force and eliminate the existing culture of our ancestors, so that the imposition of Arabization on Indonesian culture is not necessarily appropriate. Efforts to eliminate acculturation that have been passed down by previous scholars means uprooting the true character of Islam. Islam is not only oriented to divine values, but it is also friendly and pays attention to the cultural values and civilization of a nation. Islamization through cultural acculturation could be found since the time of the Prophet. Since the beginning of its development, Islam grew in the struggle of human thought and civilization. The teachings of the Prophet has reformed the Jahiliyyah traditions which were incompatible

${ }^{40}$ Imdadun Rahmat, et. al., Islam Pribumi: Mendialogkan Agama Membaca Realitas (Jakarta: Erlangga, 2003), pp. xxi-ii.

181 Moderate Islam in Local Culture Acculturation | Moh. Nailul Muna 
with human nature. ${ }^{41}$ The same pattern was later adopted by Walisongo, which shows their ability to interpret and apply Islam in accordance with the context in spreading Islam in Java.

In the end, Walisongo's efforts had implications in the subconscious dimension of the Javanese. According to KRT Jatiningrat, the philosophical essence of Javanese culture and customs is tolerance and harmony. These two things make Javanese people flexible about right and wrong, because they always look for compromise points from the various polarizations. Javanese people always live in an attitude of high tolerance. ${ }^{42}$ Islam that has lived and developed in Java since the success of Walisongo's Islamization is moderate Islam.

\section{Coclusion}

Moderation of Islam in the Indonesian archipelago originates from Islamization done by Walisongo. One of the unifying factors for regional and ethnic diversity in Indonesia is the historical legacy of Islamic moderation of Walisongo, which has instilled Islamic values that uphold moderate values, so that Islam cannot be viewed as a religion of violence.

The moderation of Islam in the Islamization done by Walisongo can be proven by the following three facts: first, Islam has come into Java in a peaceful way, therefore there was no wali who was martyred. Second, the legacy of Walisongo's teachings has been preserved up today, such as the tolerance of the Kudus community. Third, acculturation done by Walisongo is innovative and inclusive. This shows the moderation of the walis who then penetrated the Javanese society. Based on Durkheim's theory, this acceptance implies a transformation from cultural structures to social structures and then to technical structures.

\section{References}

Arif, Syaiful. "Strategi Dakwah Sunan Kudus." ADDIN: Media Dialektika Ilmu Islam, 8 (2): 245 268, http://dx.doi.org/10.21043/addin.v8i2.597.

Azra, Azyumardi. Islam Nusantara: Jaringan Global dan Lokal, trans. Iding Rasyidin. Bandung: Mizan Pustaka, 2002.

Chambert-Loir, Henri and Claude Guillot. Ziarah Wali dan Dunia Islam. Jakarta: Komunitas Bambu, 2010.

Geertz, Clifford. Agama Jawa. Jakarta: Komunitas Bambu, 2013.

\footnotetext{
${ }^{41}$ Machfud Saefuddin, et. al., Dinamika Peradaban Islam Perspektif Historis (Yogyakarta: Pustaka Ilmu, 2013), p. 2.

${ }^{42}$ Mason C. Hoadley, Islam dalam Tradisi Hukum Jawa $\mathcal{E}$ Hukum Kolonial (Yogyakarta: Graha Ilmu, 2009), p. xvii.
} 
Harun, Yahya. Islam Nusantara: Abad XVI E XVII. Yogyakarta: Kurnia Kalam Sejahtera, 1995.

Hoadley, Mason C. Islam dalam Tradisi Hukum Jawa $\mathcal{E}$ Hukum Kolonial. Yogyakarta: Graha Ilmu, 2009.

Huda, Nor. Islam Nusantara. Yogyakarta: Ar-Ruzz Media, 2013.

Ibrahim. "Ajaran Islam dalam Pandangan Harun Nasution." Aqidah-Ta: Jurnal Ilmu Aqidah, 5 (2): 131-142, https://doi.org/10.24252/aqidahta.v5i2.12286.

Karim, Abdul. Sejarah Pemikiran dan Peradaban Islam. Yogyakarta: Pustaka Book Publisher. 2007.

Kartodirdjo, Sartono. Pengantar Sejarah Indonesia Baru: 1500-1900. Jakarta: Gramedia Pustaka Utama, 1992.

Khoiri, Ahmad. "Moderasi Islam dan Akulturasi Budaya: Revitalisasi Kemajuan Peradaban Islam Nusantara." Islamadina: Jurnal Pemikiran Islam, 20 (1): 1-17, http://dx.doi.org/10.30595/islamadina.v0i0.4372.

Kuntowijoyo. Paradigma Islam: Interpretasi Untuk Aksi. Yogyakarta: Tiara Wacana, 2017.

Luthfi, Khabibi Muhammad. "Islam Nusantara: Relasi Islam dan Budaya Lokal." Shahih: Journal of Islamicate Multidisciplinary, 1 (1): 1-12, http://dx.doi.org/10.22515/shahih.v1i1.53.

Ma'arif, Ahmad Syafi'i. Islam dalam Bingkai Keindonesiaan dan Kemanusiaan. Bandung: Mizan Pustaka, 2015.

Maharsi. Islam Melayu vs Jawa Islam: Menelusuri Jejak Karya Sastra Sejarah Nusantara. Yogyakarta: Bidang Akademik, 2008.

Mubarok, Ahmad Agus and Diaz Gandara Rustam. "Islam Nusantara: Moderasi Islam di Indonesia." Journal of Islamic Studies and Humanities, 3 (2): 153-168, http://dx.doi.org/10.21580/jish.32.3160.

Pusat Bahasa Departemen Pendidikan Nasional. Kamus Bahasa Indonesia. Jakarta: Pusat Bahasa, 2008.

Rahmat, Imdadun, et. al. Islam Pribumi: Mendialogkan Agama Membaca Realitas. Jakarta: Erlangga. 2003.

Rahmatullah, Lutfi. "Eksistensi Hukum Islam di Tengah Keragaman Budaya Indonesia; Perspektif Baru Sejarah Hukum Islam dalam Bingkai Dialektika Nilai-nilai Syari'ah dan Budaya." Al-Manâhij: Jurnal Kajian Hukum Islam, 10 (1): 63-82, https://doi.org/10.24090/mnh.v10i1.917.

Said, Nur. Jejak Perjuangan Sunan Kudus dalam Membangun Karakter Bangsa. Bandung: Brillian Media Utama, 2010.

Saefuddin, Machfud, et. al. Dinamika Peradaban Islam Perspektif Historis. Yogyakarta: Pustaka Ilmu, 2013.

Sofwan, Ridin, et. al. Islamisasi di Jawa: Walisongo, Penyebar Islam di Jawa, Menurut Penuturan Babad. Yogyakarta: Pustaka Pelajar, 2004.

Sunyoto, Agus. Atlas Walisongo. Bandung: Mizan, 2016. 
Suparjo. "Islam dan Budaya: Strategi Kultural Songo dalam Membangun Masyarakat Muslim Indonesia." Komunika: Jurnal Dakwah dan Komunikasi, 2 (2): 178-193, https://doi.org/10.24090/komunika.v2i2.100.

Susanto, Edy, and Karimullah. "Islam Nusantara: Islam Khas dan Akomodasi terhadap Budaya Lokal.” Al-Ulum, 16 (1): 58-80, https://doi.org/10.30603/au.v16i1.27.

Syafrizal, Achmad. "Sejarah Islam Nusantara." Islamuna: Jurnal Studi Islam, 2 (2): 235-253, http://dx.doi.org/10.19105/islamuna.v2i2.664.

Tajuddin, Yulilatun. "Walisongo dalam Strategi Komunikasi Dakwah.” ADDIN: Media Dialektika Ilmu Islam, 8 (2): 367-390, http://dx.doi.org/10.21043/addin.v8i2.602

Wahid, Abdurrahman, et. al. Islam Nusantara. Bandung: Mizan Pustaka, 2016.

Woodward, Mark R. Islam Jawa. terj. Hairus Salim. Yogyakarta: LKiS, 2006. 